\title{
Farmers Suicide Causes and Remedies to avoid of Hingoli District in Maharashtra State : A Geo-Political View
}

\author{
Prof. Vikas V. Ade \\ Assistant Professor, Political Science, C. J. Patel Arts, Comm and Science College, Tirora, Dist. Gondia, \\ Maharashtra, India
}

\begin{abstract}
Article Info

Volume 8, Issue 4

Page Number : $322-336$

Publication Issue :

July-August-2021

\section{Article History}

Accepted : 02 Aug 2021

Published: 08 Aug 2021

The present research carried out with an exploratory design of social research on farmer's suicide of Hingoli District in Maharashtra State. These districts were The Hingoli consists of the Five Talukas (Hingoli, Kalamnuri, Basmat, Aundha, Sengaon). The average rainfall in the district is $895 \mathrm{~mm}$. About $83 \%$ of the rainfall occurs during June to September and July is the rainiest month. The maximum temperature of the district is 42.6 degree Celsius and minimum temperatures are 10.6 Degree Celsius. Over 192 farmers have committed suicide in Hingoli District between 2008 and 2017. In Hingoli District the farmer 56.25per cent, The majority of the farmers had medium extension contact 38.75per cent, Medium level of cropping intensity 83.75per cent, Medium level of economic motivation 57.50\%, deferred gratification were found 70.00 per cent in middle category, management orientation of the farmer is middle level 67.50per cent, farmers found in middle level of the indebtedness 80.00per cent, Majority of the farmer engaged in farming and farm labours 72.50per cent. Indebtedness is negative significant. The relationship was significant at 0.05 level. Major causes of farming distress is failure of crops due to drought/ lack irrigation, failure of crop due to insect disease. Indebtedness related causes increase in indebtedness is major region of distress. Major Social causes of farmer dowry and marriageable age of daughter and sister. Farmer suggests that there should be minimum support price for all crops.

Keywords : Distress, farmer, Hingoli
\end{abstract}

\section{INTRODUCTION}

The growth of agriculture and allied sectors is still a critical factor in the overall performance of the Indian economy. As per the 2010-11 advance estimates released by the Central Statistics Office (CSO) on 07.02.2011, the agriculture and allied sector accounted for 14.2 per cent of the gross domestic product (GDP), at constant 2004-05 prices $(6,7,8$ 9). In 2009-10, it accounted for 14.6 per cent of the GDP compared to 15.7 per cent in 2008-09 and 19.0 per cent in 2004-05. Its share in GDP has thus declined rapidly in the recent past $(14,15,18,19,20,31,32)$. This is explained by the fact that whereas, overall GDP has grown by an average of 8.62 per cent during 2004-05 to 2010-11, 
agricultural sector GDP has increased by only 3.46 per cent during the same period. The role of the agriculture sector, however, remains critical as it accounts for about 58 per cent of employment in the country as per 2001 census (Anonymous, 2011) Non-remunerative prices for crops, indebtedness and crop failures due to frequent droughts are by and large identified as the core reasons for farming distress $(20,21,26,27,33,34)$. The problem is compounded by the fact that the farm holdings in the country are shrinking in size, production costs are rising and the resource drain from the farm sector is mounting in recent decades. Earlier, farmers in distress might have become dacoits or rebels, but never did we hear that they committed suicides. Rao et al. (2007) stated that for the first time in the known history of India, farmers are taking recourse to suicide as a way out of agrarian distress. If farm ecology and economics go wrong nothing else will go right. This is the principal message of the agrarian crisis. The issue of farmers' 'distress' is a vexed one. 'Distress' is the result of a complex interplay of a myriad issues and risks. Therefore, it will not be prudent to address the issue in isolation of the causative factors. Farmers' 'distress' is not due to indebtedness alone. There are several other factors such as social, psychological, and family related developments that contribute significantly to this. Among the economic causes for farmers' distress, credit related issues normally play a prominent role. It has also been observed that mostly the small and marginal farmers, as well as, tenant farmers and farm labourers bear the brunt of crop failures (35, $39,40,36)$.

\section{OBJECTIVES}

\section{The objectives of the study are as follows:}

$>$ To look into the trends and patterns of the recent suicide scenario in Maharashtra.

$>$ To study the Geo-political situation of Maharashtra State.
To identify and examine other socio-economic factors leading to suicidal death by the deceased farmers.

\section{METHODS}

In this methodology conduct the data to Hindoli District of farmer suides treds and pattern and effects on 2008 to 2017 (13, 16, 17). All data collected on census of India, Divisional Commission rate Office, Aurangabad and Nagpur etc.

\section{RESULT AND ANALYSIS}

\section{Brief History of Hingoli :-}

Until 1853, the area of Hingoli district (Fig. 1) was an indivisible part of the ancient Vidharbha region. During the British rule it was the border line of the Nizam state of Hyderabad. It was a base camp for the Nizam 's troops. Military hospital, veterinary hospital for the benefit of troops was available in the area. Because of these, the area became a military cantonment and a famous town in the erstwhile Hyderabad State. There are still some localities like Phaltan, Risala, Tofkhana, and Pensionpura, Sadar Bazar etc., which reminds the oldkingdom. As stated earlier, Hingoli was part of the Parbhani district. Hingoli (Fig. 2) was famous as a placewherethesuppressionofthingscommencedin 1838 . Italsoformedacantonment till 1903 Afterwards some of the Nizam"s troops were stationed here. Today Hingoli district is well known as a trade centre and is linked both by road and rail. A market yard was established at Hingoli in 1933. Though churches are comparatively less in number, temples and mosques are plenty in the district. Among them, the temple Aundha"e (Nagnath) is famous probably, the only one structure which reminds the old history of the district. Today Hingoli district has an area of $4827.0 \mathrm{Km} 2$.

\section{Administrative:-}

Hingoli district comes under Aurangabad Administrative Division. The district of Hingoli 
consists of 5 tehsils, namely, Hingoli, Kalamnuri, Sengaon, Aundha and Basmath.

\section{Location and Geographical Data :-}

Hingoli district (Table 1) has been separated from Parbhani district and existed as an independent district from 01.05.1999. It is one of the eight districts of Marathwada. It is located at eastern site of Maharashtra State. Hingoli is situated at the northern part of Marathwada in Maharashtra. Borders of Hingoli are surrounded by Washim and Yeotmal in northern side, Parbhani in Western side and Nanded at South-Eastern side (Table 2). The district came into existence by division of Parbhani district on 1st May, 1999. Latitude of Hingoli district is $19.43 \mathrm{~N}$ and Longitude is $77.11 \mathrm{E}$. The geographical area of the district is 4526 Sq. kms; which is $1.47 \%$ of area of the Maharashtra State $(1,4,11,12,22)$.

\section{Topography:-}

The district has a grographical area of 4526 sq.kms; which forms $1.47 \%$ of the total geographicalarea of Maharashtra State. The Sengaon, Hingoli and Aundhanaganath tehsils of the district are surrounded by small hills. The district is 600 meters high from sea level (Table 3).

\section{Demography:-}

As per census 2011, Hingoli had population of 1, 177,345 of which male and female were 606,294 and 571,051 respectively. In 2001 census, Hingoli had a population of 987,160 of which males were 505373 and remaining 481787 were females. Its population growth rate over the decade 2001-2011 was $19.43 \%$. Hingoli has a sexratio of 942 females for every 1000 males, and a literacy rate of $78.17 \%$. Marathi is the official and the most spoken language in the district. Nearly $83 \%$ of the population speaks Marathi as the mother tongue. Native speakers of Deccani Urdu, Hindi and Banjari/Labhani languages are also present in significant number ((Table 4).

\section{River and Drainage:-}

The district is well drained by river systems, which are dendritic type and have matured valleys. There are three main drainage systems viz: Penganga river,
PurnaKayadu Rivers. The river Penganga originates from Ajanta hills in Buldhana. It enters in the district from Sengaon Taluka towards northeastern corner and by making a jorney of about 78 Kilometres in the district moves towards Yavatmal district. Isapur Dam is constructed on the river. It is one of the most important rivers of Deccan plateau and whole district of Hingoli falls in its greatbasin. The direct tributary of the river is Kayadhu (2, 3, 5, $23,24)$. This tributary raises from the hill ranges near Risodtaluka of Washim district. The length of the river in the district is $80.50 \mathrm{kms}$. It is a seasonal river, which dries up in summer. The Purna River rises from Ajnata hill ranges. It enters in the district from Jalna district. After making a journey of nearly 100 $\mathrm{kms}$, it moves towards Parbhani district. Yeldari and Sidheshwar dams are constructed on the river

\section{Soil:-}

The Soils of the district are derived from the basaltic lava flows. Thickness of the soil cover is less in northern and western parts where ground elevations are higher and consequently soil regur, gravels, murum are transported down to lower regions through gravity, transported down to lower regions through gravity, water or winds. Soils in central, southern and eastern regions of the district near the banks of Penganga and Purna rivers are thicker. Here soils, ranging in depth from 1 to $2 \mathrm{~m}$, are black and rich in plantnutrients.

\section{Climatic Condition:-}

The district has dry and tropical climate with hot summer and mild winter with humid SW monsoon season of moderate rainfall. In Hingoli district, monsoon starts from the month of June and ends in September. In the remaining period the weather is very dry. The average rainfall in the district is 895 $\mathrm{mm}$. About $83 \%$ of the rainfall occurs during June to September and July is the rainiest month. The maximum temperature of the district is 42.6 degree Celsius and minimum temperatures are 10.6 Degree Celsius. The air is generally dry over the district except during the southwest monsoon when the 
relative humidity is high. Winds are generally light to moderate with increase in speed during the latter half of the hot season and in monsoon season. The winds blow predominantly from directions between west and north during the hot season. They are mostly from directions between southwest and northwest during the southwest monsoonseason $(25,26,38,37)$.

\section{About District}

Hingoli is situated at the northern part of Marathwada in Maharashtra. Borders of Hingoli are surrounded by Akola and Yevotmal in northern side, Parbhani in western side and Nanded at south-eastern side. The district came into existence by division of Parbhani district on 1st may 1999. Nearest Railway Station : Hingoli. Biggest Railway Station : Parbhani which is connected to Delhi, Mumbai, Banglore, Hyderabad by direct train. Distance from Parbhani by Road : $80 \mathrm{Km}$. Distance from Akola by Train : $115 \mathrm{Km}$. Hingoli District Population, Maharashtra - Census India 2011

Hingoli is one of district of Maharashtra in India. There are 5 Talukas, 711 villages and 3 towns in Hingoli district. As per the Census India 2011, Hingoli district has 228868 households, population of 1177345 of which 606294 are males and 571051 are females. The population of children between age 0-6 is 165716 which is $14.08 \%$ of total population. The sex-ratio of Hingoli district is around 942 compared to 929 which is average of Maharashtra state. The literacy rate of Hingoli district is $67.16 \%$ out of which $74.31 \%$ males are literate and $59.57 \%$ females are literate. The total area of Hingoli is 4827 sq. $\mathrm{km}$ with population density of 244 per sq.km. Out of total population, $84.82 \%$ of population lives in Urban area and $15.18 \%$ lives in Rural area. There are $15.51 \%$ Scheduled Caste (SC) and 9.51\% Scheduled Tribe (ST) of total population in Hingoli district (Fig. 4).

\section{Hingoli Urban \& Rural Population :-}

Out of total population, $50 \%$ of population lives in Urban area and 60\% lives in Rural area.

\section{Farmers' Suicide Causes:-}

There are various economic, social, individual and environmental causes of farmers' suicide in Maharashtra. The causes of this crisis are complex and manifold; they are dominantly related to public policy and economic strategy $(28,29,30)$.

\section{Crop failure: -}

India is a agricultural land $65 \%$ of family depends on rain the probability of farming committing suicide is more during bad rain years. Inspite of the farmers work the production of the crop low which is also one of the basic cause of farmers suicide (Fig. 5).

\section{Indebtedness and low income: -}

Some time existing social structure added by agricultural distress make the situation much worse. Rural farmers often become burdened with over debt. The farmers are indebted because of low income the farmers have to face many social and financial problems. Sometimes farmers have to work as tenant which is not sufficient to lead their life and aggrieved when they become unable to arrange dowry for daughter and sisters marriage much expenditure than income daily dispute in family inability to fulfill requirement of family members lead to farmers suicide (Table 6)

\section{Prices of farm product:-}

It is often seen that when sowing season for the kharif and rubi crops come the prices of the grains reach much more but when harvesting season comes the rate drops. Due to the manipulated pricing the farmers the loser. But they are helpless and they are burdened with debts and unable to meet their commitment due being forced to sell their products at the critically reduced market rate. The government does not seen to be paying attention to this vicious circle. Nobody has tried to fix the prices based on the cost of the agricultural production. It would be seen that in the last twenty years the prices of the farm product have relatively dropped as compare to the prices of other product 


\section{Natural Calamities:-}

The effective agricultural production is mostly depends on favorable weather condition. Due to the global warming, deforestation and other manmade reasons natural condition has become more worsen and reasons like heavy raining, floods, droughts, delay in raining, heavy cyclones etc. farmers unable to take qualitative and quantitative production from their farm. Even all the condition are in favor of farmers and production is good in quality \& quantity farmers don't get proper return of their product in the market, as more supply of goods

reduces demand and reduction in demands automatically reduces price of the same. Most of the time farmers are unable to recover cost price of their product. Due to these reasons agriculture becomes an assured loss making business. But the marginal \& small farmers of India don't have another option for earning. They again \& again put their all efforts in the agriculture. Continuous losses turn them to become insolvent and frustration of the same forces them to commit suicides.

\section{Increase in cost of production:.}

Agriculture sector in India requires huge manpower for ploughing, digging, soil maintenance etc., for insecticides, pesticides, cutting, transportation and selling of products requires money In addition to this hybrid seeds are also requires for good quality \& quantity of product, which are very costly and not affordable to marginal and poor farmers. Increase in cost of production which forces to farmers to commit suicide (Table 7).

\section{Cruel circle of money lenders loan :-}

for the production of agro product farmers are always in great need of short or long term loans similarly there is also great need of money for farming related activities like taking bore well, pipeline setting purchasing seeds ,bees, tractors and others related things to the farm. But there are lot hindrances and impediments while sanctioning such lone amount to the farmers by bank finalizing all the related documents is almost like an ordeal. So most of the farmers at the critical time traditional source of money as like savkar, money lenders come to their help and sanctions loan immediately but charges interest at the very high rate even after accepting all such adversities a natural calamities make a great sabotage to the farm and finally the farmers are totally collapsed because not a single agro product is encased. At last they are left with no option. The continuous pressure from money lenders for the payment of loans and their inability to repay the lone complete, farmers to commit suicide.

\section{Illiteracy, Traditions \& Culture}

Due to illiteracy and inadequate knowledge, farmers do not believe in importance of education. Lack of education skills their decision making skills. Lack of money and perception capacity, They are cultivating land in traditional method if farmers fail to perform all these tradition and cultural activities they become frustrate and turn towards suicide.

\section{Agricultural marketers}

The product farm farmer takes to the market the agricultural betrays the farmer and they have to sell their crop in the lower rate (Fig. 3).

\section{New changes}

After the green revolution and innovation of new technologies new hybrid seeds, insecticides, pesticides and farm cultivation technologies makes farming more easier and production is increased considerably. But these technologies and innovations are so costly and not affordable to poor small and marginal farmers $(42,43)$.

\section{Income inequality in economy}

Today, the person who is rich is becoming rich and one who is poor is becoming poor therefore the valley of reciprocal economy is increasing day by day so the farmers are turning to suicide.

\section{Costly modern agriculture technique}

After the green revolution and innovation of new technologies new hybrid seeds, insecticides, pesticides and farm cultivation technologies makes farming more easier and production is increased considerably. But these technologies and innovations are so costly 
and not affordable to poor small and marginal farmers $(41,44)$.

\section{Other Causes}

lack of basic infrastructural facilities like safe drinking water, inadequate health facilities, transport facilities, proper food, cloth and shelter affects on psychological and physical condition of the farmers. Sometimes they become drug addicted and drunker. All these things attracted heavy diseases and turn them to die.

13. Rehabilitation packages e.g. Package of Central Government, Package of State Government, Lone Waiver Proposal, etc are not implementing in proper way to relief needy farmers.

\section{Remedies to avoid farmers suicides:-}

The above natural and manmade calamities forces farmers to commit suicides. We cannot avoid natural calamities but we can give relief \& control on manmade calamities by taking following measures:

\section{Financial Help: Rupees}

1 Lakh has been sanctioned as Financial help for Farmers who had attempted Suciude from the government of Maharashtra. 2008 to 2017. 155 lakh Rs. has been distbut the suciuded farmer . to avoid farmers suicide Government of India and concern state governments must give subsidies to the farmers. while delivering these subsidies prefer ence must be given to marginal and small farmers. they should get free of cost hybrid seeds as they have small piece of productive land. If they have given subsidies for the same. It should be given in cash and before the sowing seeds. Which will help to avoid malpractices and corruption in distribution of seeds and subsidies. In addition to this while deciding small and marginal farmers farming of total family is taken into consideration instead of single landholders of each family.

\section{Effective loan schemes:}

The government should establish special system while providing loan to farmers. Every Nationalize and cooperative bank including Agriculture co-operative credit societies must setup this system in their banks to provide loan to the farmers on time and as per their requirements. At the same time loans should be provided at low rate of interest. So that farmers should not be exploited and not discriminated by private moneylenders and creditors.

\section{Effective loan waiving scheme:}

After consideration of high numbers of farmers suicides; In 2016, government of India and concern states also declared packages. according to the data of year 2017, out of the total 192 farmers suicide in Hingoli District. Cotton were in debt. Which means needy farmers didn't get the benefits of such relief packages. And package of 1075 crore from chief minister of Maharashtra packages concern governments should directly deposits money to the bank accounts.

\section{Export policies}

The Government of India and Concern state governments always make bias and takes irresponsible decision in export of Agricultural products. They use to ban on export of agricultural products when their prices are high. This is resulted to more supply in local market and falling in prices.

\section{Irrigation facilities:}

Indian farmers facing problems of irrigation. Geographical condition in India is varied for every region. Some regions facing problem of heavy rainfall and some regions are comes under drought prone area. Due to failure of water management heavy rainfall area and drought prone area also facing problems of irrigation in rainy as well as off rain season like summer.

\section{Policy about MRPs:}

According to the Agricultural policy of GOI, it is binding on concern state government to declare MRPs of all agricultural products before the agricultural production comes out. But till 2010, all state governments have declared MRPs less than the cost of all agricultural products. So, GOI and concern state governments must declare MRPs which at least gives minimum profit or follow a policy of MRP which is Cost of Production $+30 \%$. 


\section{Other Remedies}

In addition to above measures GOI and all concern state governments must help to farmers for development of allied activities of Agriculture and support for farmers oriented small scale and agriproducts industries. This helps to increase standard of living, solve financial problems and fulfill their basic, safety and prestigious needs.

Table 1. District at Glance

\begin{tabular}{|c|c|c|}
\hline Sr. No & Particulars & Statistics \\
\hline 1. & & \\
\hline & \multicolumn{2}{|c|}{ GENREAL INFORMATION } \\
\hline & Geographical Are & 4526 Sq.km \\
\hline & Talukas & 05 \\
\hline & Villages & 707 \\
\hline & Grampanchayat & 563 \\
\hline & Population (Census, 2011) & $11,78,973$ \\
\hline & Normal Annual Rainfall & $1824.4 \mathrm{~mm}$ \\
\hline \multirow[t]{3}{*}{2.} & \multicolumn{2}{|r|}{ GEOMORPHOLOGY } \\
\hline & Major Physiographic unit & Ajintha Hills \\
\hline & Major Drainage & Kayadhu, Purna, Painganga \\
\hline 3. & SOIL TYPE & Black Cotton Soil \\
\hline 4. & GEOLOGY & Basaltic Deccan Trap \\
\hline \multirow[t]{3}{*}{5.} & \multicolumn{2}{|r|}{ HYDROGEOLOGY } \\
\hline & Water Bearing Formation & Fractured, Jointed, Vesicular, \& Weathered Basalt \\
\hline & Ground Water Quality & $\begin{array}{c}\text { Drinkable however localized fluoride contamination } \\
\text { aquifer and nitrate contamination in some parts of } \\
\text { urban areas of Hingoli town and localized places in } \\
\text { ruralareas. }\end{array}$ \\
\hline
\end{tabular}

Table 2. Geographical Information

\begin{tabular}{|c|c|c|}
\hline Sr. No. & Area & 4526 sq. kms. \\
\hline 1 & Latitude & $19.43 \mathrm{~N}$ \\
\hline 2 & Longitude & $77.11 \mathrm{E}$ \\
\hline 3 & Sub-divisions & Three ( Hingoli, Kalamnuri, Basmat) \\
\hline 4 & Talukas & Five (Hingoli, Kalamnuri, Basmat, Aundha, Sengaon) \\
\hline 5 & Languages & Marathi, Hindi, Urdu \\
\hline 6 & Folk- Arts & Gondhal, Shahiri, Bharud, Potraj, Kalgitura \\
\hline
\end{tabular}


Prof. Vikas V. Ade Int J Sci Res Sci Eng Technol, July-August-2021, 8 (4) : 322-336

\begin{tabular}{|c|c|c|}
\hline 7 & Maximum Temperature & 42.6 Deg.C \\
\hline 8 & Minimum Temperature & 10.6 Deg.C. \\
\hline 9 & Main Crops & Jowar, Cotton \\
\hline 10 & & 4526 sq. kms. \\
\hline
\end{tabular}

Table 3. Month Wise Rainfall Data of (2019) of Hingoli District

\begin{tabular}{|l|l|l|l|}
\hline Month & Normal Rain & Actual Rain & Rainy Days \\
\hline January & 5.1 & - & - \\
\hline February & 6.2 & - & - \\
\hline March & 7.9 & - & - \\
\hline April & 6.4 & - & - \\
\hline May & 12.8 & - & - \\
\hline June & 168.5 & 87.9 & 10 \\
\hline July & 258.9 & 232.1 & 15 \\
\hline August & 251 & 193.2 & 13 \\
\hline September & 160.1 & 234.9 & 17 \\
\hline October & 46.3 & 166.7 & 16 \\
\hline November & 20.6 & 23.8 & 1 \\
\hline December & 12.5 & 2.1 & 0 \\
\hline Total & 956.3 & 940.7 & 72 \\
\hline
\end{tabular}

(Source: Agriculture Department, Maharashtra)

Table 4. Land-use pattern

\begin{tabular}{|l|l|l|}
\hline Sr.No. & Particulars & Area Details (In Sq.km) \\
\hline 1. & Area not available for cultivation & 192 \\
\hline 2. & Other uncultivable land & 294.2 \\
\hline 3. & Area under forest & 192 \\
\hline 4. & Fallow land & 595.6 \\
\hline 5. & New sown area & 3253 \\
\hline
\end{tabular}

Table 5. Hingoli Religion Population

\begin{tabular}{|l|l|l|}
\hline \multicolumn{1}{|c|}{ Description } & Population & Percentage \\
\hline Total & 1177345 & $100 \%$ \\
\hline Hindu & 863199 & $73.32 \%$ \\
\hline Buddhist & 176679 & $15.01 \%$ \\
\hline Muslim & 127552 & $10.83 \%$ \\
\hline Jain & 5278 & $0.45 \%$ \\
\hline Religion not stated & 2899 & $0.25 \%$ \\
\hline Christian & 992 & $0.08 \%$ \\
\hline Sikh & 643 & $0.05 \%$ \\
\hline Other religions and persuasions & 103 & $0.01 \%$ \\
\hline
\end{tabular}


Table 6. Farmer Suciude in Hingoli District :- (2008- 2017)

\begin{tabular}{|c|c|c|c|c|c|c|c|}
\hline Sr. No. & District & Year & $\begin{array}{l}\text { Total } \\
\text { Suciude }\end{array}$ & Eligible & $\begin{array}{l}\text { Not } \\
\text { Eligible }\end{array}$ & $\begin{array}{l}\text { Delay due to } \\
\text { Pending } \\
\text { Enquire }\end{array}$ & $\begin{array}{l}\text { Solved } \\
\text { Cases }\end{array}$ \\
\hline 1 & \multirow{11}{*}{ Hingoli } & 2008 & 12 & 10 & 02 & 0 & 10 \\
\hline 2 & & 2009 & 09 & 02 & 07 & 0 & 02 \\
\hline 3 & & 2010 & 02 & 01 & 01 & 0 & 01 \\
\hline 4 & & 2011 & 05 & 00 & 05 & 0 & 0 \\
\hline 5 & & 2012 & 03 & 02 & 01 & 0 & 02 \\
\hline 7 & & 2013 & 02 & 02 & 00 & 0 & 02 \\
\hline 8 & & 2014 & 31 & 25 & 06 & 0 & 25 \\
\hline 9 & & 2015 & 41 & 34 & 07 & 0 & 34 \\
\hline \multirow[t]{3}{*}{10} & & 2016 & 49 & 41 & 08 & 0 & 41 \\
\hline & & 2017 & 38 & 27 & 07 & 04 & 27 \\
\hline & & Total & 192 & 144 & 44 & 04 & 144 \\
\hline
\end{tabular}

(Source: District Office Hingoli)

Table 7. Number of farmers suicides in Marathwada region (2010-2017)

\begin{tabular}{|c|c|c|c|c|c|c|c|c|c|}
\hline Year & $\begin{array}{c}\text { Auranga } \\
\text { bad }\end{array}$ & Latur & Beed & Prabhani & Jalna & Hingoli & Osmanabad & Nanded & Total \\
\hline 2010 & 02 & 04 & 79 & 22 & 04 & 02 & 23 & 55 & 191 \\
\hline 2011 & 00 & 04 & 73 & 23 & 06 & 05 & 25 & 33 & 169 \\
\hline 2012 & 02 & 00 & 91 & 35 & 06 & 03 & 22 & 39 & 198 \\
\hline 2013 & 04 & 03 & 98 & 17 & 08 & 02 & 29 & 146 & 207 \\
\hline 2014 & 56 & 44 & 152 & 70 & 32 & 31 & 71 & 118 & 574 \\
\hline 2015 & 144 & 106 & 301 & 104 & 83 & 41 & 164 & 190 & 1133 \\
\hline 2016 & 151 & 116 & 222 & 989 & 76 & 49 & 161 & 180 & 1053 \\
\hline 2017 & 139 & 94 & 207 & 125 & 91 & 56 & 126 & 153 & 991 \\
\hline Total & 498 & 371 & 1223 & 494 & 306 & 189 & 621 & $\mathbf{8 1 4}$ & 4516 \\
\hline
\end{tabular}

(Source: Divisional Commission rate Office, Aurangabad) 


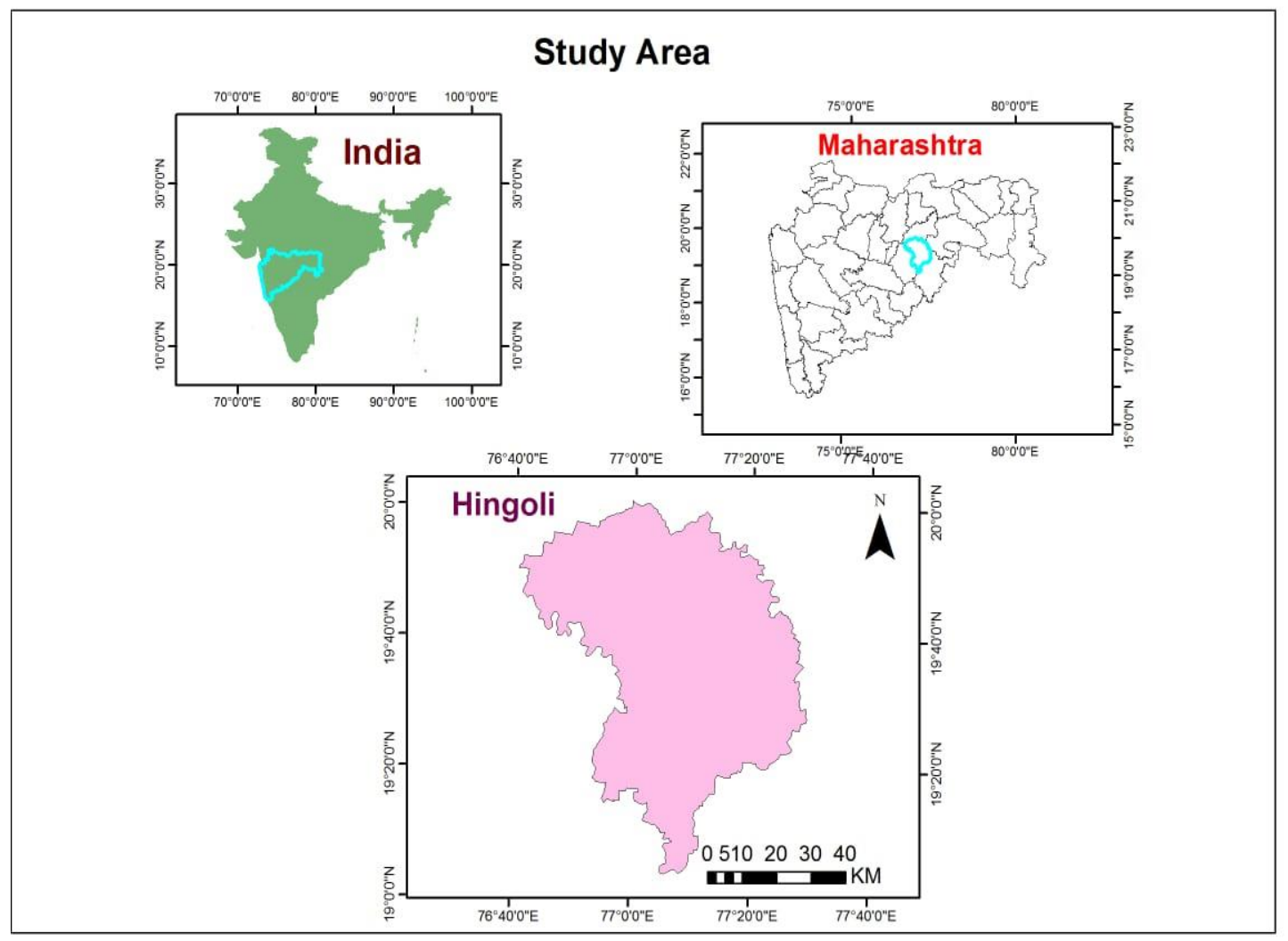

Fig. 1. Study Area

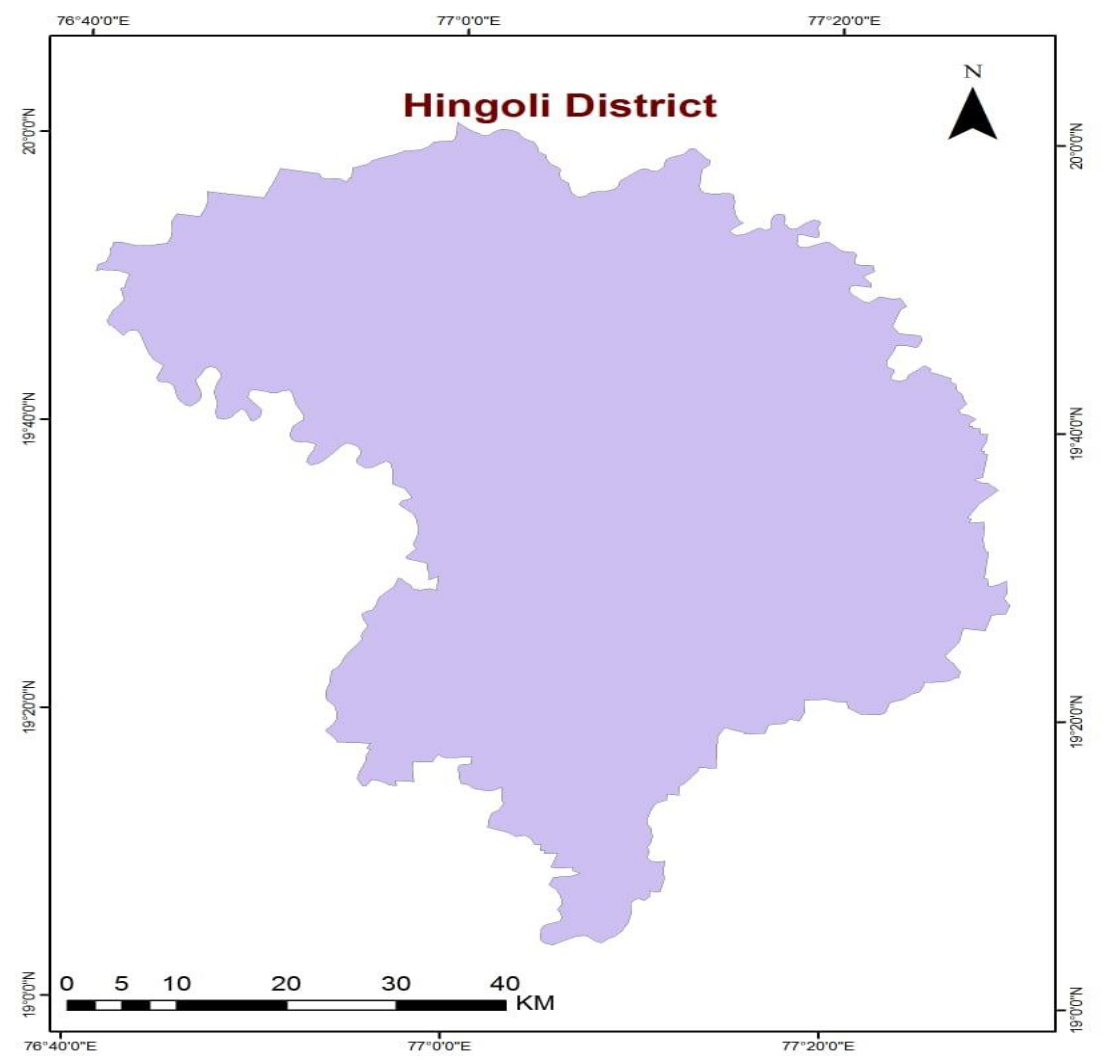

Fig. 2. Hingoli District 


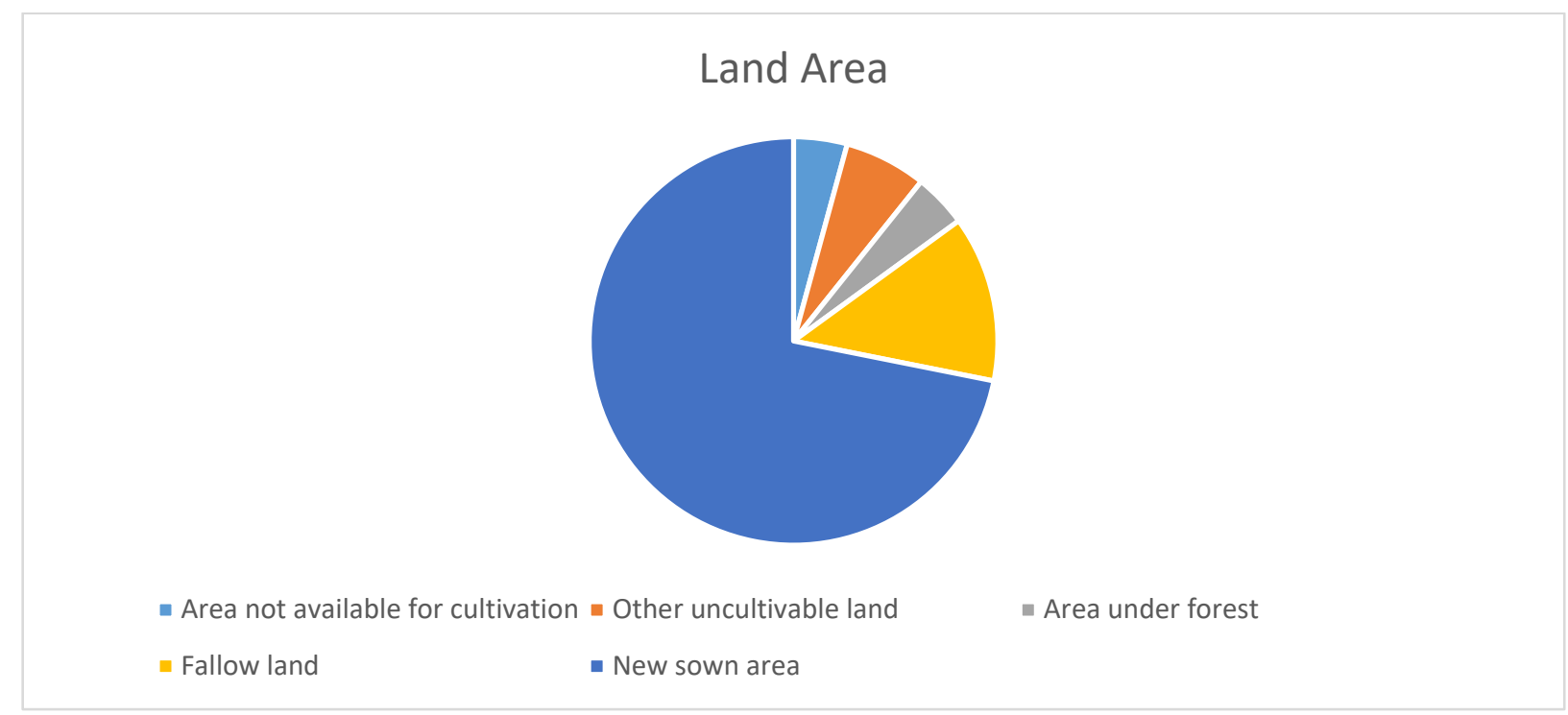

Fig. 3. Land Use Area.

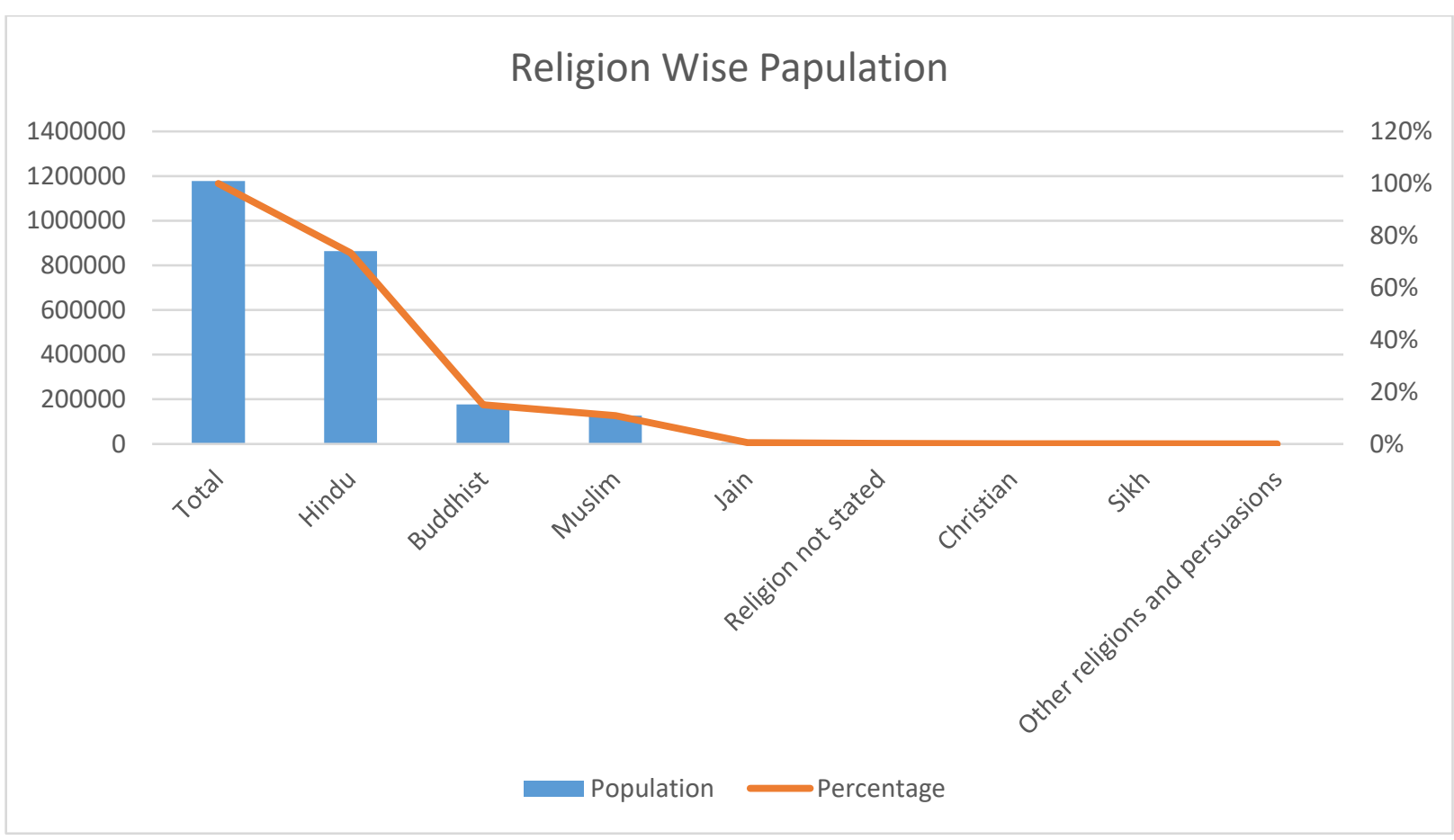

Fig. 4. Population 


\section{Farmers Suciude in Hingoli District}

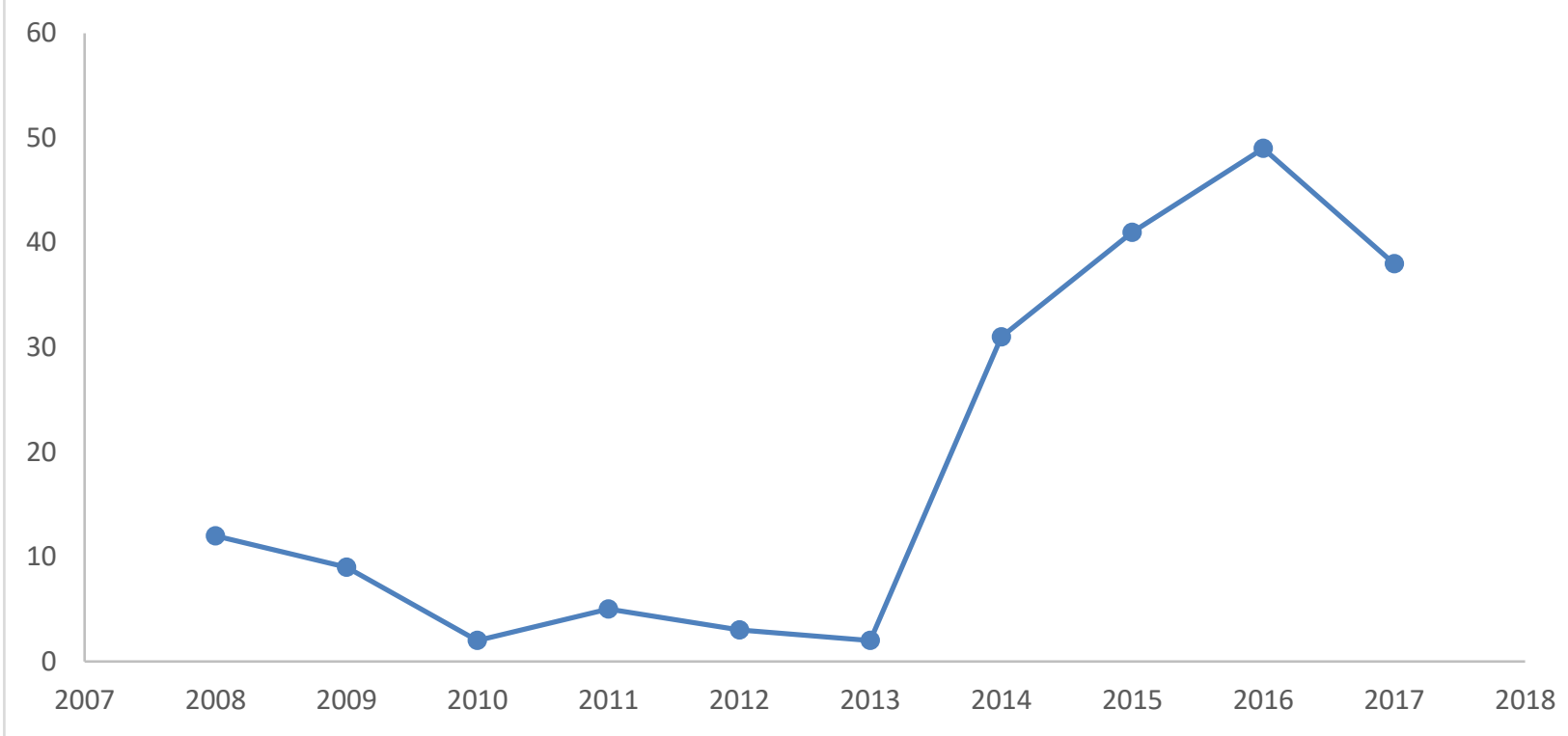

Fig. 5. Farmers Suciude in Hingoli District.

\section{REFERENCES}

[1]. Ade V.V (2021) Trends and Causes of Farmers Suicide in Maharashtra State, India, International Journal of Scientific Research in Science, Engineering and Technology, Volume 8 ,Issue 1,PP. : 248-261. doi : https://doi.org/10.32628/IJSRSET218145

[2]. Ade V.V (2019): Farmers' Suicide In Vidarbha Region Of Maharashtra State: A Geo-Political View, Think India Journal, pp-12723-12732.

[3]. Ade V.V (2020): Farmers' Suicide In Marathawada Region Of Maharashtra State: A Geo-Political View, Our Heritage, Vol-68Issue,pp- 10251- 10263.

[4]. Ade V.V (2015) : Human Right;s and India, Review Of Research Journal, Volume 4 Issue12,PP-1-06.

[5]. Ade V. V. (2019) Relevance of Mahatma Gandhi;s Economical Philosophy, Multidisciplinary International E-Research Journal Peer Reviewed Journal, Volume 203,Issue 06,PP-186-191
[6]. Alston M.( 2012) Rural male suicide in Australia. Soc Sci Med.;74(4):515-22.

[7]. Andersen K, Hawgood J, Klieve H, Kõlves K, De Leo D, (2010): Suicide in selected occupations in Queensland: evidence from the state suicide register. Aust N Z J Psychiatry. https://doi.org/10.3109/00048670903487142.

[8]. Batterham P, Callear A, Christensen H. (2013) Correlates of suicide stigma and suicide literacy in the community. Suicide Life Threat Behav. 43(4):406-17.

[9]. Behere Prakash (2008): Farmers' suicide in Vidarbha region of Maharashtra state: A myth or reality, Indian Journal of Psychiatry 50(2):124-7, https:// doi:10.4103/00195545.42401

[10]. Bhattacharyya, S., Venkatesh, P., Aditya, K.S. et al. (2020). The Macro and Micro Point of View of Farmer Suicides in India. Natl. Acad. Sci. Lett. 43 , 489-495 https://doi.org/10.1007/s40009-020-00920-4

[11]. Bisen D.K and Kudnar N.S. (2013): A Sustainable Use and Management of Water Resource of the Wainganga River Basin: - A 
Traditional Management Systems. figshare. Journal contribution. https://doi.org/10.6084/m9.figshare.663573.v1

[12]. Bisen D.K and Kudnar N.S. (2019) Climatology, Sai Jyoti Publication, Nagpur.pp-11-211.

[13]. Dandekar, A., Narawades, S., Rathod, R., Ingle, R., Kulkarni, V., \& Sateppa, Y. D. (2005): Causes of Farmer Suicides in Maharashtra: An Enquiry (Final Report Submitted to the Mumbai High Court). Tuljapur: Tata Institute of Social Sciences, Rural Campus.

[14]. Gadekar D.J, Sonkar S. (2020). Statistical Analysis of Seasonal Rainfall Variability and Characteristics in Ahmednagar District of Maharashtra, India. International Journal of Scientific Research in Science and Technology, 2395-6011, doi https://doi.org/10.32628/IJSRST207525

[15]. Gadekar D.J, Sonkar S. (2021). The Study of Physico-Chemical Characteristics of Drinking Water: A Case Study of Nimgaon Jali Village, International Advanced Research Journal in Science, Engineering and Technology, 8, 61-65.

[16]. Desai P. T. (2006): India Today, Farmers suicide. Delhi: Living Media India Ltd; February 27.

[17]. Deshpande, R. (2002). Suicide by Farmers in Karnataka: Agrarian Distress and Possible Alleviatory Steps. Economic and Political Weekly, 37(25): 2601-2610.

[18]. Gutierrez, A.P., Ponti, L., Kranthi, K.R. et al. (2020). Correction to: Bio-economics of Indian hybrid Bt cotton and farmer suicides. Environ Sci Eur 32, 162 https://doi.org/10.1186/s12302020-00445-z

[19]. Hofle, A. (2015). Farmers' Suicides in India: A Methodological and Thematic Analysis in the State of Maharashtra (Master Thesis). South Asia Institute - Department of Anthropology, Heidelberg University.
[20]. Iyer, K., \& Manick, M. (2000). Impoverishment and Suicides in Rural Punjab. New Delhi: Indian Publishers Distributors.

[21]. Judd F, Jackson H, Fraser C, Murray G, Robins G, Komiti A.(2006) Understanding suicide in Australian farmers. Soc Psychiatry Psychiatr Epidemiol.;41(1):1-10.

[22]. Kennedy, A.J., Versace, V.L. \& Brumby, S.A. (2016) Research protocol for a digital intervention to reduce stigma among males with a personal experience of suicide in the Australian farming community. BMC Public Health16,1204. https://doi.org/10.1186/s12889016-3874-3

[23]. Kleiman EM, Riskind JH, Schaefer KE, Weingarden H. (2012): The moderating role of social support on the relationship between impulsivity and suicide risk. Crisis. https://doi.org/10.1027/0227-5910/a000136.

[24]. Kudnar, N. S., (2017): Morphometric Analysis of the Wainganga River Basin Using Traditional \& GIS Techniques, Ph.D. Thesis, Rashtrasant Tukadoji Maharaj Nagpur University, Nagpur, Pp 66-250.

[25]. Kudnar, N. S., (2018): Water Pollution a Major Issue in Urban Areas: A Case Study of the Wainganga River Basin, Vidyawarta International Multidisciplinary Research Journal, pp 78-84.

[26]. Kudnar, N. S., (2019): Impacts of GPS-Based Mobile Application for Tourism: A Case Study of Gondia District, Vidhyawarta, PeerReviewed International Publication, pp-19-22.

[27]. Kudnar, N.S., (2020) GIS-based assessment of morphological and hydrological parameters of Wainganga river basin, Central India. Model. Earth Syst. Environ. 6, 1933-1950. https://doi.org/10.1007/s40808-020-00804-y

[28]. Kudnar, N.S. \& Rajasekhar, M, (2019): A study of the morphometric analysis and cycle of erosion in Waingangā Basin, India, Model. 
Earth Syst. Environ, pp-117.https://doi.org/10.1007/s40808-019-00680-1

[29]. Kudnar, N. S. Padole, M. S et al (2021) "Traditional crop diversity and its conservation on-farm for sustainable agricultural production in Bhandara District, India", International Journal of Scientific Research in Science, Engineering and Technology (IJSRSET), Online ISSN: 2394-4099, Print ISSN : 2395-1990, Volume 8 Issue 1, pp. 35-43, January-February 2021. Available at doi : https://doi.org/10.32628/IJSRSET207650

[30]. Milner A, Hjelmeland H, Arensman E, De Leo D. (2013): Social-environmental factors and suicide mortality: a narrative review of over 200 articles. Sociol Mind. https://doi.org/10.4236/sm.2013.32021.

[31]. Mishra, S. (2006) Suicide of Farmers in Maharashtra (Submitted to the Government of Maharashtra). Mumbai: Indira Gandhi Institute of Development Research.

[32]. Mishra, S. (2014). Farmers' Suicides in India, 1995-2012: Measurement and Interpretation (Asia Research Center Working Paper 62). London: London School of Economics \& Political Science Houghton Street.

[33]. Mohanty, B., \& Shroff, S. (2004). Farmer's Suicides in Maharashtra. Economic and Political Weekly, 39(52): 5599-5606.

[34]. National Crime Records Bureau (1999): Accidental Deaths and Suicides in India. Ministry Of Home Affairs. New Delhi: Government of India.

[35]. Pawar AP, Kapse PS, Bodke BG and PK Waghamare (2019) -Socio-economic and psychological characteristics of distress farmers in Hingoli district, Journal of Pharmacognosy and Phytochemistr.www.phytojournal.com-pp 80-84

[36]. Perceval, M., Ross, V., Kõlves, K. et al. (2018) Social factors and Australian farmer suicide: a qualitative study. BMC Public Health 18, 1367. https://doi.org/10.1186/s12889-018-6287-7

[37]. Rajasekhar M, Sudarsana Raju G, et al (2021) Multi-criteria Land Suitability Analysis for Agriculture in Semi-Arid Region of Kadapa District, Southern India: Geospatial Approaches, Remote Sensing of Land, 5(2), 5972. https://doi.org/10.21523/gcj1.2021050201

[38]. Salunke V. S., Kudnar N. S. et al., (2020) Application of Geographic Information System (GIS) for Demographic Approach of Sex Ratio in Maharashtra State, India, International Journal for Research in Applied Science \& Engineering Technology (IJRASET), Volume 8 Issue XI, pp-259-275

[39]. Salunke V. S., Bhagat R. S. et al., (2020) Geography of Maharashtra, Prashant Publication, Jalgaon, pp- 1-229.

[40]. Salunke, V. S., Lagad, S. J., et al. (2021) "A Geospatial Approach to Enhance Point of the Interest and Tourism Potential Centers in Parner Tehsil in Maharashtra, India", International Journal of Scientific Research in Science, Engineering and Technology (IJSRSET), Online ISSN : 2394-4099, Print ISSN : 2395-1990, Volume 8 Issue 1, pp. 186-196, Available at doi https://doi.org/10.32628/IJSRSET218136

[41]. Sonawane, S.T. (2016) Critical Study of Farmers Suicide in Maharashtra- Causes and Remedies, International Journal of Innovative Research in Science, Engineering and Technology, Vol. 5, Issue $\quad 11, \quad$ pp-20150-20155. DOI:10.15680/IJIRSET.2016.0511149

[42]. Srinagesh Mannekote Thippaiah, Suresh Bada Math, Muralidhara Shankarapura Nanjappa (2019): Suicide in India: A preventable epidemic, The Indian Journal of Medical Research 150(4):324 https://doi.org/10.4103/ijmr.IJMR_1805_19

[43]. Taylor R, Page A, Morrell S, Harrison J, Carter G.(2005) Social and psychiatric influences on 
urban-rural differentials in Australian suicide.

Suicide Life Threat Behav.;35(3):277-90.

[44]. Torok, M., Shand, F., Phillips, M. et al.(2019)

Data-informed targets for suicide prevention: a small-area analysis of high-risk suicide regions in Australia. Soc Psychiatry Psychiatr Epidemiol 54, 1209-1218. https://doi.org/10.1007/s00127-019-01716-8

\section{Cite this article as :}

Prof. Vikas V. Ade, "Farmers Suicide Causes and Remedies to avoid of Hingoli District in Maharashtra State : A Geo-Political View", International Journal of Scientific Research in Science, Engineering and Technology (IJSRSET), Online ISSN : 2394-4099, Print ISSN : 2395-1990, Volume 8 Issue 4, pp. 322-336, July-August 2021. Available at doi : https://doi.org/10.32628/IJSRSET218453

Journal URL : https://ijsrset.com/IJSRSET218453 